\title{
PERBANDINGAN HASIL JADI PAES PADA WAJAH PENGANTIN
}

\author{
Vonny F.S Hartini Hipij \\ vonnyhippy@yahoo.com
}

\begin{abstract}
Abstrak
Latar belakang penelitian ini adalah pengembangan potensi peserta didik dalam menghadapi perkembangan industry. Pengembangan tersebut adalah pada spengembangan pembuatan paes secara proposional. Penelitian ini merupakan penelitian eksperimen dengan 20 peserta didik untuk tiga materi dengan tiga pertemuan. Data dianalisis menggunakan prosentase dengan instrument lembar pengamatan, angket dan tes. Hasil penelitian secara umum menunjukkan hasil paes yang paling bagus pada bentuk wajah kotak.
\end{abstract}

Kata kunci: belajar, paes, metode proposional.

\section{PENDAHULUAN}

Dasar kurikulum 2013 adalah budaya dan karakter bangsa serta kompetensi. Pengembangan kompetensi peserta didik dipengaruhi oleh lingkungan belajar dan karakteristik dari peserta didik.

Peserta didik pada pendidikan kejuruan memiliki hubungan erat dengan kebutuhan tenaga kerja saat ini. Lulusan pendidikan kejuruan banyak dibutuhkan oleh industry. Industry salon saat ini sedang mengalami perkembangan yang sangat pesat, sehingga lulusan pendidikan kejuruan diharapkan mampu berperan serta dalam pesatnya pertumbuhan industry tersebut.

Di industry, pelakon usaha tidak dapat memilih konsumen yang baik, sempurna dan proporsional. Berdasarkan hasil wawancara dengan alumni, bahwa masalah terbesar yang dihadapi adalah metode pembuatan paes yang kurang akurat. Metode yang lama dirasakan kurang luwes dengan wajah klien yang terkesan kaku dan aneh.

Berdasarkan alasan tersebut diatas maka perlu dilakukan penelitian tentang pembuatan paes dengan metode proposional pada pengantin solo. Dari alasan tersebut maka dapat dirumuskan masalah sebagai berikut"bagaimana hasil pembuatan paes metode proposinal?".

Bertolak dari masalah dan rumusan tersebut diatas maka tujuan dari penelitian ini adalah menghasilkan metode baru guna menyiasati masalah yang mungkin akan dihadapi oleh peserta didik.

\section{KAJIAN PUSTAKA Belajar}

Proses belajar adalah tindakan untuk memahami arti dalam belajar. Belajar merupakan sebuah konsepsi yang fundamental. Proses belajar adalah penjelasan dari cara pandang yang ditelaah dari sudut pandang teori berpikir.

Menurut Christian Wolff, bahwa pikiran merupakan kumpulan dari beberapa kekuatan yang terpisah. Kegiatan berpikir mengekspresikan diri melalui indera dan melatih ingatan, imajinasi, keinginan, penilaian dan daya nalar. Maka dapat disimpulkan bahwa belajar adalah melatih berpikir dan mengembangkan kekuatan nalar, persepsi dan ingatan.

Sedangkan Thorndike memandang belajar dari sudut pandang teori koneksionis yakni teori yang mengacu pada stimulus atau respon peserta didik yang didasarkan pada konsep bahwa koneksi terbentuk antara situasi dan respon. Berdasarkan pandangan ini behwa belajar terjadi melalui perubahan antara stimulus dan respon.

Watson memandang belajar dari sudut pandang behaviorisme, yakni kondisi reflex merupakan inti dari pembelajaran yang terbentuk dari kebiasaan. Manusia belajar melalui perilaku yang diamati.

\section{Paes Pengantin Solo}

Paes adalah gambar atau riasan hitam pada dahi pengantin. Paes pengantin solo putri awalnya dibuat menggunakan medote tradisional yakni menggunakan jari perias. Ukuran yang kurang fleksibel, maka memerlukan ketajaman perias dalam membuat. Metode tradisonal selama ini di populerkan dengan ukuran jari.

Ukuran jari yang biasa digunakan dalam metode tradisional adalah sebagai berikut: Gajahan, menggunakan ukuran empat jari, pengapit menggunakan ukuran dua jari, 
penitis menggunakan ukuran dua jari setengah, dan ukuran godeg menggunakan satu jari jempol.

Untuk mengatasi masalah kebakuan ukuran maka peneliti membuat ukuran secara proporsional. Adapun ukuran tersebut didasari oleh tiga item yaitu sudut matabagian luar, sudut mata bagian dalam dan hidung.

\section{METODE PENELITIAN}

Penelitian ini merupakan jenis penelitian eksperimen melalui pendekatan sebab akibat dengan subjek mahasiswa prodi tata rias universitas adi buana Surabaya.

Penelitian dilaksanakan pada saat perkuliahan melalui 3 kali pertemuan pada wajah buah diamond, wajah kotak dan wajah bulat dengan rancangan penelitian one short case study. Data dikumpulkan melalui metode pengamatan, metode angket, metode tes dan di analisis menggunakan prosentase $(\%)$.

\section{HASIL DAN PEMBAHASAN}

Pengamatan hasil pembuatan paes pada tiga bentuk wajah buah diamond, wajah kotak dan wajah bulat. Hasil yang diperoleh secara akan peneliti deskripsikan sebagai berikut:

Pembuatan paes pada wajah diamond. Hasil pembuatan paes secara proposional pada wajah diamond mampu menutupi dan menyamarkan dahi yang kecil.

Pembuatan paes proposional pada wajah kotak diperoleh hasil yang paling baik. Penerapan metode tersebut sangat cocok dengan wajah model yang lebar dan panjang. Wajah model terlihat lebih oval.

Hasil pembuatan paes proposional pada wajah bulat dapat menyamarkan bagian samping wajah model sehingga wajah tampak oval.

Ketiga hasil diatas akan peneliti jabarkan sebagai berikut:

Penelitian dilakukan pada mahasiswa sejumlah 20 orang dengan 3 materi dan 3 kali pertemuan. Hasil akan peneliti sajikan dalam table berikut:

\begin{tabular}{|c|c|c|c|}
\hline Siswa & Diamond & Kotak & Bulat \\
\hline 1 & B+ & B+ & A- \\
\hline 2 & B & A- & B+ \\
\hline 3 & B & B+ & B+ \\
\hline 4 & B - & B & B+ \\
\hline 5 & B+ & B+ & A- \\
\hline 6 & A- & B+ & B+ \\
\hline 7 & B+ & A- & B \\
\hline
\end{tabular}

\begin{tabular}{|c|c|c|c|}
\hline 8 & B & B+ & A- \\
\hline 9 & B + & A- & B+ \\
\hline 10 & B + & B+ & A- \\
\hline 11 & A & B+ & B+ \\
\hline 12 & A- & B & B+ \\
\hline 13 & B + & B + & B+ \\
\hline 14 & B & B+ & A- \\
\hline 15 & B+ & A- & A- \\
\hline 16 & A & B+ & B+ \\
\hline 17 & B & A- & B+ \\
\hline 18 & B & B+ & B \\
\hline 19 & A- & B & B+ \\
\hline 20 & B + & A & B+ \\
\hline
\end{tabular}

Sumber Peneliti

\section{KESIMPULAN}

Dari hasil penelitian diatas dapat disimpulkan bahwa perbandingan hasil pembuatan paes secara proposional bergantung pada kemampuan gambar desain yang di miliki oleh peserta didik. Selain itu proposional paes juga dipengaruhi oleh posisi bola mata model yakni posisi normal, juling kedua-dua atau juling sebelah.

Panjang dan pendeknya paes tergantung pada panjang dan pendeknya alis serta mata. Penelitian lanjutan boleh dilakukan untuk bentuk wajah selaiin tersebut diatas.

\section{REFERENSI}

Arikunto, Suharsimi. 2010. Dasar - dasar Evaluasi Pendidikan. Jakarta : Bumi Aksara.

Arikunto, Suharsimi. 2012. Prosedur penelitian suatu pendekatan praktik. Jakarta : PT Rineka Cipta

Ibrahim, Muslimin. 2010. Pembelajaran Berdasarkan Masalah. Surabaya : UNESA University Press.

Ibrahim, Muslimin. 2011. Asesmen Berkelanjutan. Surabaya : UNESA University Press.

Kusumadewi, dkk. 1999. Pengetahuan dan Seni Tata Rambut Modern Tingkat Mahir. Jakarta Selatan : PT Carina Indah Utama.

Nasution, S. 2012. Pengembangan Kurikulum. Bandung : PT CITRA ADITYA BAKTI.

Nursalim, Mochamad, dkk. 2010. Psikologi Pendidikan. Surabaya : UNESA University Press. 
Riduwan. 2006. Metode dan Teknik Menyusun Tesis. Bandung : ALFABETA.

Riduwan. 2009. Variable PengukuranPenelitian. Bandung : ALFABETA.

Riduwan. 2009. Skala Pengukuran Variabel variabel Penelitian. Bandung : ALFABETA. 